\title{
Is the routine measurement of ionized calcium worthwhile in patients with cancer?
}

\author{
José A. Riancho, Rafael Arjona, Jaime Sanz, José M. Olmos, Reina Valle, \\ José R. Barceló and Jesús González-Macías
}

Departmento de Medicina Interna and Sección de Oncología, Hospital M. Valdecilla, Facultad de Medicina, 39008 Santander, Spain

\begin{abstract}
Summary: This study was undertaken to analyse the relationship between total calcium (TCa) and ionized calcium (ICa) in patients with cancer, and to assess the clinical value of routine measurements of ICa in these patients. Serum TCa, ICa, albumin, proteins and creatinine were measured in 188 adult patients with solid malignant tumours. Most of them were out-patients, the Karnofsky score being 80 or above in $67 \%$. The correlation coefficient between ICa and TCa was $0.85(P<0.001)$ and did not improve after correcting TCa for protein concentration with several published formulae. Although TCa measurements had a global diagnostic accuracy (percent of patients correctly classified) of $90 \%$, they failed to identify a substantial proportion of patients with increased levels of ICa (57\% for uncorrected TCa, and 27-57\% for protein-corrected TCa). However, the finding of slightly increased ICa levels did not seem to predict the development of frank hypercalcaemia and did not impair the prognosis. According to these results, the routine measurement of $\mathrm{ICa}$ in unselected patients with cancer has no clinical usefulness.
\end{abstract}

\section{Introduction}

Hypercalcaemia is a well-recognized complication of cancer, and hypocalcaemia also seems to be frequent in some clinical settings. ${ }^{1}$ About $50 \%$ of calcium in serum is bound to proteins, especially albumin. Since patients with cancer frequently have reduced serum albumin concentrations, the measurement of total calcium (TCa) might not reflect the status of the biologically important ionized calcium (ICa). On the other hand, the value of several formulae devised for correcting TCa for protein concentration abnormalities is not well established in cancer patients. Indeed, the metabolic derangements frequently observed in these patients, including an accelerated lipolysis, may change the binding of calcium to albumin, as has been shown in other processes. ${ }^{2}$ This study was undertaken to elucidate: (a) how TCa and ICa correlate in patients with cancer; (b) the influence of correcting $\mathrm{TCa}$ for protein concentration in the correlation between $\mathrm{TCa}$ and $\mathrm{ICa}$; and (c) the clinical value of routine measurements of $\mathrm{ICa}$ in cancer patients.

Correspondence: Professor J. González-Macías, M.D. Accepted: 15 October 1990

\section{Materials and methods}

\section{Patients}

The study was prospectively conducted on 188 consecutive adult patients with histologically proven malignant tumours [mean age $60 \pm 13$ years (s.d.), 104 males, 84 females]. Most of them were out-patients. The Karnofsky score $^{3}$ was 80 or above in $67 \%$ of the patients, and only $11 \%$ had a score of 50 or below. The most frequent tumour sites were: lung, 35 patients; breast, 34; skin, 28; urinary tract, 17; colon, 15; unknown primary site, 14; head and neck, 10; and stomach, 7. Bone metastases were present in $17 \%$ of the patients, liver metastases in $15 \%$, and pleuropulmonary metastases in $16 \%$. Ninety-eight patients were followed up for a maximum of 14 months; 60 died during the follow-up.

\section{Techniques}

Blood was drawn in the morning after overnight fasting for the measurement of ICa, TCa, albumin, total proteins and creatinine. ICa was measured in serum samples obtained under anaerobic conditions with a NOVA 7 analyser (NOVA Biomedical, Waltham, MA, USA), which displays both the actual $\mathrm{ICa}$ and the $\mathrm{ICa}$ expected for $\mathrm{pH}=7.4$, in 
order to compensate for $\mathrm{pH}$ alterations during sample processing. Since gross abnormalities of acid-base status were unlikely in most patients, the figure of ICa corrected for $\mathrm{pH}=7.4$ was used in the analysis of results. The day-to-day coefficient of variation $(\mathrm{CV})$ was $1.2 \%$. TCa $(\mathrm{CV}=2.3 \%)$ and the other biochemicals were measured with a Hitachi 730 autoanalyser.

\section{Data analysis}

TCa measurements were corrected for albumin and protein concentrations following four published formulae. ${ }^{4-7}$ They were also corrected using the coefficients derived from the regression of calcium on albumin in the present series, as described by other authors. ${ }^{6.8}$ The correlation coefficients were calculated by the least-squares method. The survival plots were obtained with the Kaplan-Meier method and compared with the log-rank and Wilcoxon-Gehan tests.

\section{Results}

The mean results are shown in Table I. A low-level correlation existed between TCa and protein concentration $(r=0.28, P<0.01)$. This and other correlations are shown in Table II. The correlations between TCa and ICa did not improve when TCa was corrected with the coefficients derived from our own regression of calcium on albumin with the methods of Payne ${ }^{6}$ and Sorva ${ }^{8}$ and therefore they are not shown. Excluding from the analysis patients with serum creatinine higher than 0.13 $\mathrm{mmol} / 1(n=21)$ did not significantly modify the results of the correlation analysis. However, unexpectedly, the correlation coefficients between $\mathrm{TCa}$ and ICa were higher in the subset of patients with the worst clinical status (as assessed by Karnofsky scale or serum albumin levels, Table II).

Table I Mean biochemical values (and ranges in parentheses). Corrected ICa refers to the ICa value expected for $\mathrm{pH}=7.4$

\begin{tabular}{lcc}
\hline & Mean \pm s.d. & $\begin{array}{c}\text { Normal } \\
\text { range }\end{array}$ \\
\hline Actual ICa (mmol/l) & $1.26 \pm 0.14$ & $1.15-1.35$ \\
Corrected ICa (mmol/l) & $(0.99-2.37)$ & \\
& $1.30 \pm 0.14$ & $1.15-1.35$ \\
TCa $(\mathrm{mmol} / \mathrm{l})$ & $2.03-2.53)$ & \\
& $(1.77-4.26$ & $2.10-2.63$ \\
Albumin $(\mathrm{g} / \mathrm{l})$ & $41 \pm 6$ & $35-55$ \\
& $(18-52)$ & \\
Proteins $(\mathrm{g} / \mathrm{l})$ & $72 \pm 7$ & $55-80$ \\
& $(43-92)$ & \\
\hline
\end{tabular}

Table II Correlation coefficients between ICa and total calcium, either uncorrected (TCa) or corrected for protein concentrations with four published formulae (TCa-1 through $\mathrm{TCa}-4)$. The references are given in brackets. The results of the entire group and the subgroups with the poorest health status are shown. Every coefficient is associated with a $\boldsymbol{P}$ value less than 0.001

\begin{tabular}{lccc}
\hline & $\begin{array}{c}\text { All } \\
\text { patients } \\
(n=188)\end{array}$ & $\begin{array}{c}\text { Karnofsky } \\
<=50 \\
(n=21)\end{array}$ & $\begin{array}{c}\text { Albumin } \\
<35 \mathrm{~g} / \mathrm{l} \\
(n=26)\end{array}$ \\
\hline $\mathrm{TCa}$ & 0.85 & 0.95 & 0.94 \\
$\mathrm{TCa}-1[3]$ & 0.85 & 0.95 & 0.92 \\
TCa-2 [4] & 0.87 & 0.96 & 0.95 \\
$\mathrm{TCa}$ [5] & 0.86 & 0.96 & 0.95 \\
TCa-4 [6] & 0.87 & 0.96 & 0.95 \\
\hline
\end{tabular}

Looking at individual values, both the uncorrected and the corrected TCa determinations failed to detect a significant proportion of patients with abnormalities in $\mathrm{ICa}$, and misclassified as abnormal a few patients who actually had normal ICa levels (Table III). Most patients with abnormal ICa and normal TCa had ICa levels slightly higher than the reference range. Moreover, they did not usually develop frank hypercalcaemia during the followup.

In order to study the influence of the calcaemic status on prognosis, the survival curves of patients with normal and increased ICa and TCa serum levels were compared (because of the low number of hypocalcaemic patients, they were excluded from the analysis). As shown in Figure 1, patients with high TCa had a reduced survival when compared with those with normal TCa (median 1 versus 7 months; $P<0.001$ ). However, no significant difference was observed between patients with high and normal ICa levels ( 3 versus 5 months; $P=0.57$ by the $\log$-rank test and $P=0.09$ with the Wilcoxon-Gehan statistic). Nevertheless, patients

Table III Diagnostic accuracy in 188 patients of total calcium determinations, either uncorrected (TCa) or corrected as in Table II (TCa-1 through TCa-4). The results are given as the number of patients correctly classified (percent in parentheses), in the group as a whole and in the subgroups with normal or abnormal ICa value.

\begin{tabular}{|c|c|c|c|c|}
\hline & \multirow[b]{2}{*}{$\begin{array}{l}\text { All patients } \\
(n=188)\end{array}$} & \multicolumn{3}{|c|}{ Ionized calcium } \\
\hline & & $\begin{array}{c}\text { High } \\
(n=23)\end{array}$ & $\begin{array}{c}\text { Normal } \\
(n=163)\end{array}$ & $\begin{array}{c}\text { Low } \\
(n=2)\end{array}$ \\
\hline $\mathrm{TCa}$ & $169(90)$ & $10(43)$ & $158(97)$ & 1 \\
\hline TCa-1 & $171(91)$ & $10(43)$ & $160(98)$ & 1 \\
\hline TCa-2 & $171(91)$ & $17(73)$ & $154(94)$ & 0 \\
\hline TCa-3 & $166(88)$ & $10(43)$ & $156(96)$ & 0 \\
\hline TCa-4 & $174(93)$ & $16(70)$ & $158(97)$ & 0 \\
\hline
\end{tabular}




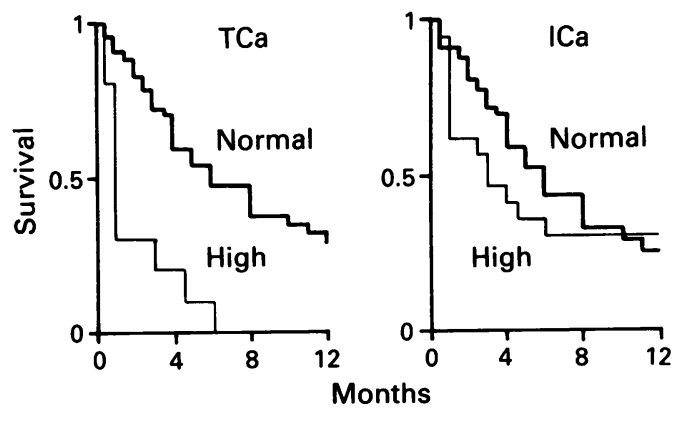

Figure 1 Kaplan-Meier survival plots of patients with normo- and hypercalcaemia, as assessed by uncorrected total calcium (TCa, left) and ionized calcium (ICa, right).

with ICa above $1.5 \mathrm{mmol} / \mathrm{l}$ had a shorter survival than those with normal or mildly increased ICa (1 versus 6 months; $P<0.001$ ).

\section{Discussion}

Ionized calcium is recognized as the biologically active form of calcium in the extracellular fluid, but measurement of $\mathrm{TCa}$ is the usual routine test for the diagnosis of hypo- and hypercalcaemia, due to its inclusion in autoanalysers and lower cost. There is controversy about the clinical utility of routine ICa measurements. ${ }^{8-15}$ Many authors feel that $\mathrm{TCa}$, eventually corrected for protein concentration, is usually sufficient for clinical purposes. However, marked disagreements in the assessment of calcium status by TCa and ICa analysis have been found in some situations, including critically ill subjects ${ }^{2}$ and elderly in-patients. ${ }^{8}$

In the present study we addressed the issue of the usefulness of routine ICa measurement in cancer patients, a population prone to derangements of calcium homeostasis. Although most of our patients were not critically ill, TCa analysis failed to identify $57 \%$ of the patients diagnosed as hypercalcaemic by ICa measurements, and also misclassified some patients who actually had normal or low ICa levels. Overall, these results confirm the findings of a previous short report. ${ }^{16}$ Correcting $\mathrm{TCa}$ for protein concentration with some published formulae did not increase the correlation coefficients between $\mathrm{TCa}$ and ICa (Table II), but it seemed to improve the concordance between $\mathrm{TCa}$ and $\mathrm{ICa}$
(Table III). Only $14 \%$ of our patients had reduced levels of albumin. The correction of $\mathrm{TCa}$ for protein concentration may have a more important influence on the relation between TCa and ICa in groups of patients with higher prevalence of hypoalbuminaemia. ${ }^{9,11}$ Most discrepancies between $\mathrm{TCa}$ and ICa values took place in patients whose results were close to the dividing line between normal and abnormal. Misclassification of some patients might be due to the unavoidable experimental error in measuring ICa and TCa. Nevertheless, the analytical imprecision would be expected to account for TCa and ICa conflicting results only in $6-7 \%$ of patients, as calculated by Thode with methods showing coefficients of variation close to those observed in our study. ${ }^{11}$ Other factors that have been implicated in the discrepancies between corrected $\mathrm{TCa}$ and $\mathrm{ICa}$ results are the endogenous interindividual variation in calcium binding to albumin, ${ }^{8}$ and the influence of serum bicarbonate, citrate and free fatty acids. . $^{12,17}$

Given the discrepancies between ICa and TCa measurements found in this study, the question of the utility of the routine analysis of ICa in cancer patients could be raised. However, we observed that those patients with mildly increased ICa levels and normal TCa did not usually develop frank hypercalcaemia during the follow-up, in spite of the absence of specific therapy. It has been reported that elderly subjects with high ICa levels have an increased mortality, whereas such a distinction could not be established on the basis of $\mathrm{TCa}$ levels. ${ }^{18}$ However, in our study TCa was a better predictor of prognosis than ICa. This finding seemed to be related to the greater sensitivity of ICa measurements. Patients with frank hypercalcaemia did have a worse prognosis. However, some patients had mild hypercalcaemia (that is, mildly increased ICa and normal TCa levels), which did not appear to impair the survival.

In summary, disagreements between $\mathrm{TCa}$ and ICa measurements are frequent in cancer patients, even when individuals with preserved general status are considered. Thus, between one-third and one-half of patients with mildly increased ICa are undetected by $\mathrm{TCa}$ determinations, either corrected for proteins or not. However, these mild degrees of hypercalcaemia do not seem to have a negative influence on the prognosis, or identify patients who later develop frank hypercalcaemia. These results do not support the usefulness of routine measurements of $\mathrm{ICa}$ in cancer patients.

\section{References}

1. Riancho, J.A., Arjona, R., Valle, R., Sanz, J. \& GonzálezMacias, J. The clinical spectrum of hypocalcaemia associated with bone metastases. J Intern Med 1989, 226: 449-452.

2. Zaloga, G.P. \& Chernow, B. Hypocalcemia in critical illness. JAMA 1986, 256: 1924-1929. 
3. Karnofsky, D.A. \& Burchenal, J.H. The clinical evaluation of chemotherapeutics agents in cancer. In: Macleod, C.M. (ed.). Evaluation of Chemotherapeutic Agents. Columbia University Press, New York, 1949, pp. 199-205.

4. Parfitt, A.M. Correction of plasma calcium measurements. $\mathrm{Br}$ Med J 1974, i: 520.

5. Berry, E.M., Gupta, M.M., Turner, S.J. \& Burns, R.R Variations in plasma calcium with induced changes in plasma specific gravity, total protein, and albumin. Br Med J 1973, iv: $640-643$.

6. Payne, R.B., Little, A.J., Williams, R.B. \& Milner, J.R. Interpretation of serum calcium in patients with abnormal serum proteins. $\mathrm{Br}$ Med J 1973, iv: 643-646.

7. Blomqvist, C.P. A hospital survey of hypocalcaemia in patients with malignant disease. Acta Med Scand 1986, 220: 167-173.

8. Sorva, A., Elfving, S., Pohja, P. \& Tilvis, R.S. Assessment of calcaemic status in geriatric hospital patients: serum ionized calcium versus albumin-adjusted total calcium. Scand J Clin Lab Invest 1988, 48: 489-494.

9. Iqbal, S.J., Giles, M., Ledger, S., Nanji, N. \& Howl, T. Need for albumin adjustments of urgent total serum calcium. Lancet 1988, ii: $1477-1478$.

10. Larsson, L. \& Ohman, S. Correcting total serum calcium. Lancet 1989, i: 326.

11. Thode, J., Juul-Jorgensen, B., Bhatia, H.M. et al. Comparison of serum total calcium, albumin-corrected total calcium, and ionized calcium in 1213 patients with suspected calcium disorders. Scand J Clin Lab Invest 1989, 49: 217-223.
12. White, T.F., Farndon, J.R., Conceicao, S.C., Laker, M.F., Ward, M.K. \& Kerr, D.N.S. Serum calcium status in health and disease: a comparison of measured and derived parameters. Clin Chim Acta 1986, 157: 199-214.

13. Marshall, R.W. \& Hodgkinson, A. Calculation of plasma ionized calcium from total calcium, proteins and $\mathrm{pH}$ : comparison with measured values. Clin Chim Acta 1983, 127: 305-310.

14. Pedersen, K.O. An analysis of measured and calculated calcium quantities in serum. Scand J Clin Lab Invest 1978, 38: 659-667.

15. Conceicao, S.C., Weightman, D., Smith, P.A., Luno, J., Ward, M.K. \& Kerr, D.N.S. Serum ionised calcium concentration: measurement versus calculation. $\mathrm{Br} \operatorname{Med} J$ 1978, i: $1103-1105$.

16. Shemerdiak, W.P., Kukreja, S.C., Lad, T.E., York, P.A.J. \& Henderson, W.J. Evaluation of routine ionized calcium determination in cancer patients. Clin Chem 1981, 27: $1621-1622$.

17. Zaloga, G.P., Willey, S., Tomasic, P. \& Chernow, B. Free fatty acids alter calcium binding: a cause for misinterpretation of serum calcium values in critical illness. $J$ Clin Endocrinol Metab 1987, 64: 1010-1014.

18. Sorva, A. \& Tilvis, R. Survival and calcaemic status of geriatric inpatients. Lancet 1987, ii: 799. 